\title{
MASS BALANCE OF TWO HIGH ARCTIC PLATEAU ICE CAPS
}

\author{
By RAYMond S. BRADley and MARK C. SERREze
}

(Department of Geology and Geography, University of Massachusetts at Amherst, Amherst,

Massachusetts 01003, U.S.A.)

ABstract. Mass-balance measurements have been renewed on two small ice caps on north-eastern Ellesmere Island. Original stake networks were established in 1972 and 1976. Since then, both ice caps have experienced significant mass losses averaging -70 to $-140 \mathrm{~kg} \mathrm{~m}^{-2} \mathrm{a}^{-1}$. They have also decreased in area. The equilibrium line in this area has averaged around $1150 \mathrm{~m}$ for the last decade or so. The ice caps are remnants of former climatic conditions and are out of equilibrium with contemporary climate.

\section{INTRODUCTION}

The Hazen Plateau of north-eastern Ellesmere Island, N.W.T., Canada, is a broad upland area extending $70 \mathrm{~km}$ from the United States Range in the west to Robeson Channel in the east (Fig. 1). The upland is dissected by deep glacial troughs, which formerly drained ice from the mountains in the north-west towards the south-east. Hill summits are extremely flat, generally exceeding $600 \mathrm{~m}$ in elevation and occasionally reaching $>850 \mathrm{~m}$ a.s.l. (Fig. 2). Most of these upland surfaces are currently unglacierized, the local glaciation level ranging from $\sim 700 \mathrm{~m}$ to $\sim 1000 \mathrm{~m}$ (Miller and others, 1975). A notable exception to this is the area north of St. Patrick Bay (Fig. 1) where two small ice caps occur; these are the north-easternmost ice bodies in the Queen Elizabeth Islands. They are referred to, unofficially, as the St. Patrick Bay ice caps. The larger of the two ice caps is the primary focus of this paper.

Meteorological studies on and around the ice caps will be discussed elsewhere (papers in preparation by R.S. Bradley and M.C. Serreze).

\section{PREVIOUS WORK}

No reference to the ice caps has been located in any historical literature in spite of the fact that they are relatively close to where both the Nares and Greely expeditions spent considerable time (in 1875-76 and 1881-84, respectively). In particular, the Greely expedition explored much of the area around Fort Conger, but no notation of these features was made. Possibly, extensive snow cover on the higher reaches of the plateau in the late nineteenth century would have made Greely and others oblivious to their presence.

Photographic coverage of the ice caps is quite good beginning with the Polaris trimetrogon survey in 1947 (Table I). Although of poor quality, these photographs show extremely snow-free conditions across the Hazen Plateau at the time of the survey (24 July) (Fig. 2). Similar conditions prevailed in 1959; by 6 July, all winter accumulation had disappeared and the underlying dirt-laden ice was exposed (Fig. 3). Low-level coverage in 1974 followed a period of snowfall so the ice caps appear snow-covered, even though the surrounding plateau was snow-free at that time (4 August). Finally, low-level coverage was repeated in 1978, revealing a dirt-laden ice surface with melt-water channels clearly visible.

The ice caps were first visited in 1972 when conditions, late in the ablation season, were radically different from those shown on the 1959 aerial photographs.
By 20-21 August there was "partial cover of winter snow all around the ice margin for at least a kilometer" (Hattersley-Smith and Serson, 1973). A network of eight
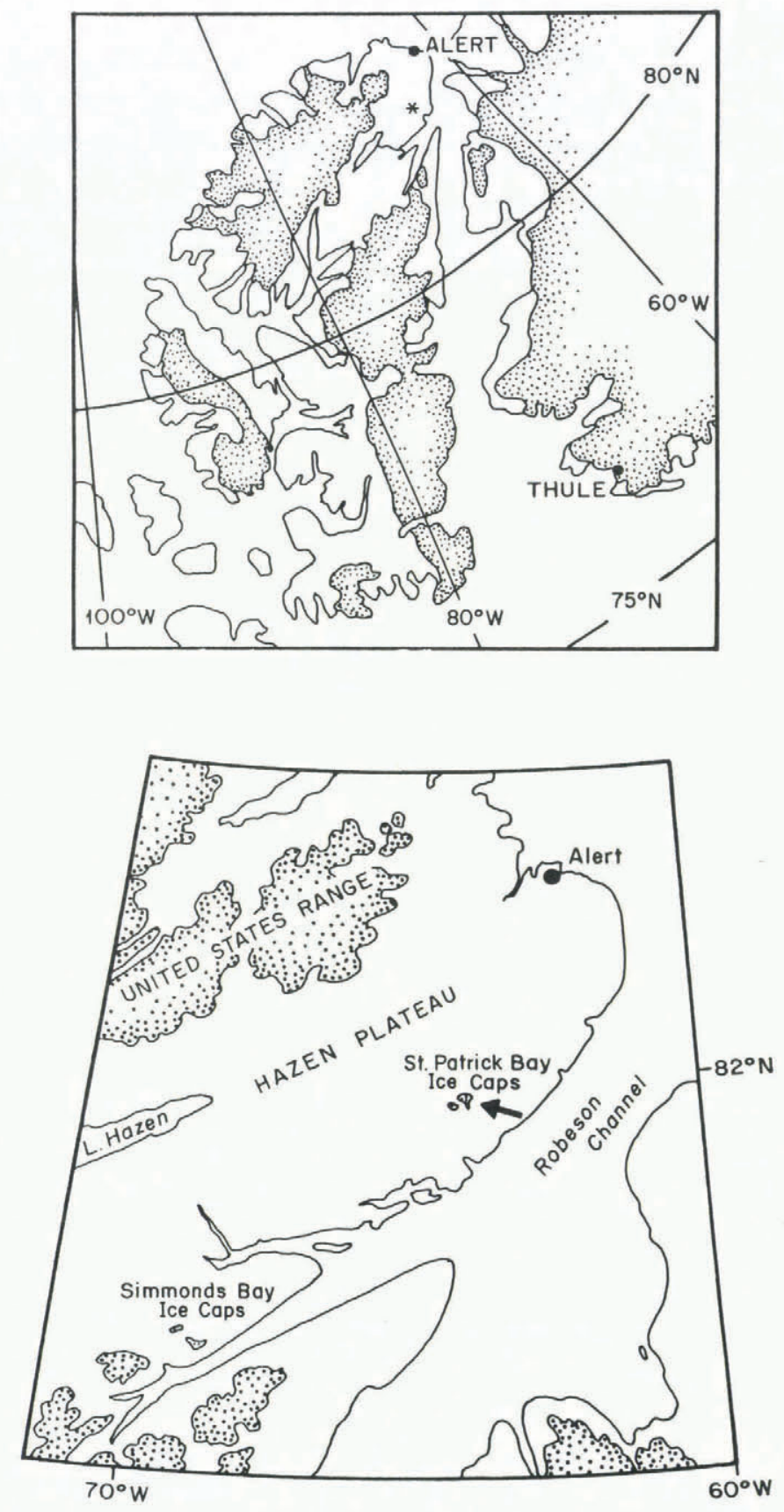

Fig. 1. Location map: north-eastern Ellesmere Island, N.W.T., Canada. Arrow refers to view shown in Figure 2. 


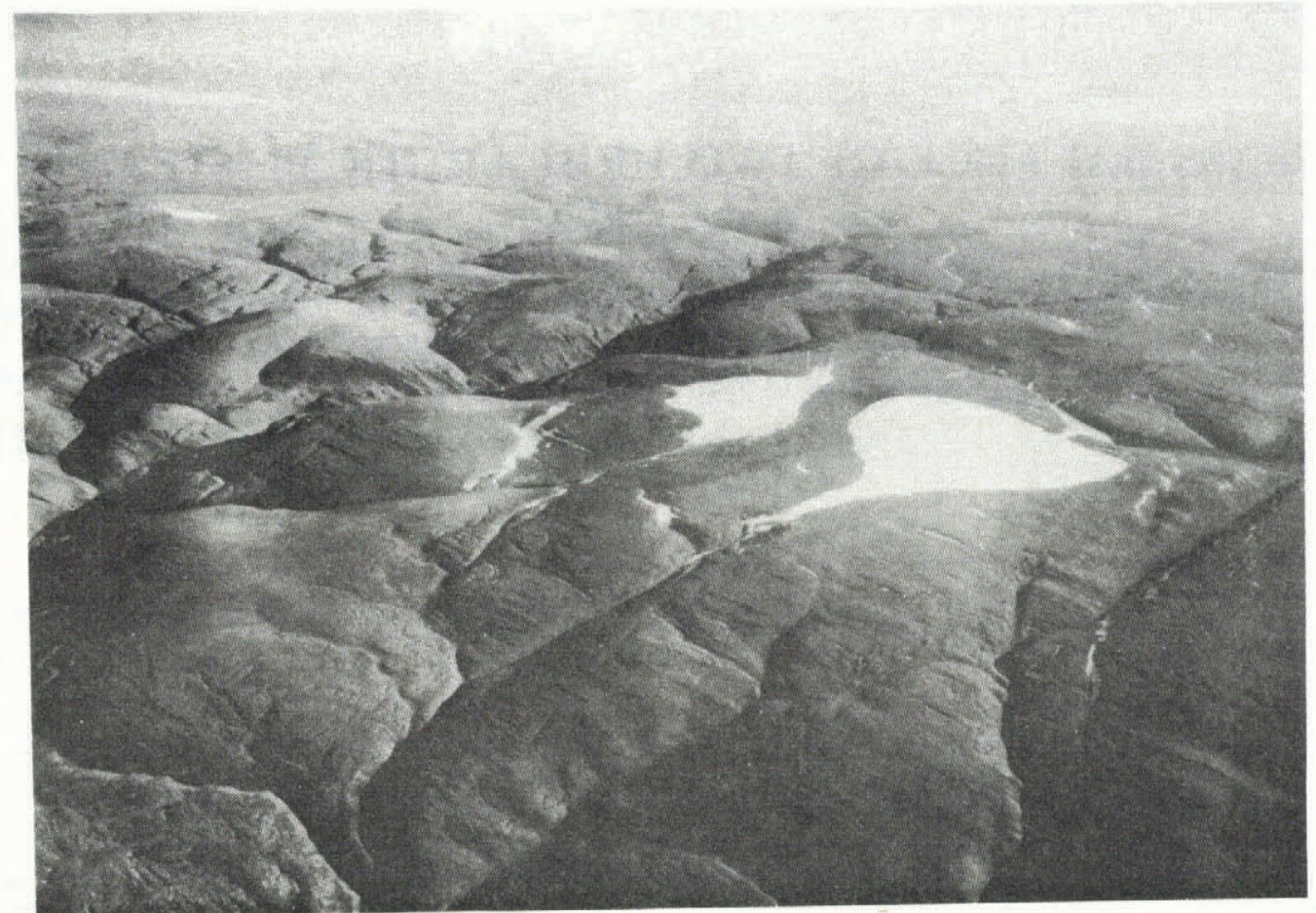

Fig. 2. Oblique aerial photograph of Hazen Plateau looking towards United States Range and Lake Hazen (left, rear) from location of arrow in Figure 1. (Copyright: Canadian Nalional Map Collection: NMC-7M154 186 RT, 24 July 1947.)

TABLE I. AERIAL PHOTOGRAPHS OF THE ST. PATRICK BAY ICE CAPS

\begin{tabular}{|c|c|c|c|c|}
\hline Date & Survey & Scale & Type & Conditions \\
\hline 24 July 1947 & Polaris & & Oblique only & $\begin{array}{l}\text { Plateau completely snow- } \\
\text { free }\end{array}$ \\
\hline & Trimetrogon & & Black and white & \\
\hline 6 July 1959 & $\begin{array}{l}\text { Department of } \\
\text { Energy, Mines and } \\
\text { Resources }\end{array}$ & $1: 80000$ & $\begin{array}{l}\text { Vertical and } \\
\text { oblique } \\
\text { Black and white }\end{array}$ & $\begin{array}{l}\text { Plateau and ice caps snow- } \\
\text { free; ice-cap surface is } \\
\text { dirt-laden ice showing } \\
\text { layering and surface- } \\
\text { drainage channels }\end{array}$ \\
\hline 4 August 1974 & $\begin{array}{l}\text { Glaciology } \\
\text { Division }\end{array}$ & $1: 20000$ & $\begin{array}{l}\text { Vertical } \\
\text { Color }\end{array}$ & $\begin{array}{l}\text { Plateau snow-free; ice caps } \\
\text { with snow cover possibly } \\
\text { from just before the } \\
\text { survey }\end{array}$ \\
\hline 1 August 1978 & $\begin{array}{l}\text { Glaciology } \\
\text { Division }\end{array}$ & $1: 23000$ & $\begin{array}{l}\text { Vertical } \\
\text { Color }\end{array}$ & $\begin{array}{l}\text { Plateau and ice caps snow- } \\
\text { free, prominent ablation } \\
\text { surface on ice caps, dirt- } \\
\text { laden melt-water channels } \\
\text { visible }\end{array}$ \\
\hline
\end{tabular}

ablation stakes was installed at that time; one additional stake was added in 1975 (personal communication from $\mathrm{H}$. Serson). The area was not re-visited until the summers of 1982 and 1983 when a topo-climatic study of the ice caps was initiated by the University of Massachusetts. As part of this work, the original stake line was re-surveyed. A more extensive stake network was established (Fig. 4a) and two extensive snow-depth and density surveys were made. Five stakes were also installed on the smaller (south-western) ice cap in 1983. In addition, an ablation-stake network, which was established in June 1976 on Simmonds Bay ice cap, $\sim 110 \mathrm{~km}$ to the south-west (Bradley and England, 1977), was re-surveyed in July 1983 (Fig. 1). Results of these measurements are discussed in the next section. The radiation-climate, energy-balance, and topo-climatic studies carried out on the main St. Patrick Bay ice cap in 1982 and 1983 will be reported elsewhere (papers in preparation by R.S. Bradley and M.C. Serreze).

\section{ICE-CAP ELEVATION AND MASS BALANCE}

Elevations of stakes and other features are shown in Table II. Repeated measurements with a precision surveying altimeter provided an internally consistent set of elevations relative to base camp (Station Yankee; Fig. 3). Helicopter traverses to sea-level provided estimates of base-camp elevation. We estimate the stake elevations shown in Table II are accurate to within $\pm 1 \mathrm{~m}$ relative to one another and within $10 \mathrm{~m}$ of absolute elevations relative to sea-level. The important point is that the entire elevational range of the larger ice cap is only about $50 \mathrm{~m}$, with a summit elevation of approximately $900 \mathrm{~m}$. It is thus extremely flat, and similar in elevation to the surrounding unglacierized hills. Considering its topographic setting, the ice cap is probably no more than $25 \mathrm{~m}$ thick at the summit. The smaller ice cap to the west does not cover a hill summit and is entirely lower than the larger ice cap. It is situated on a 


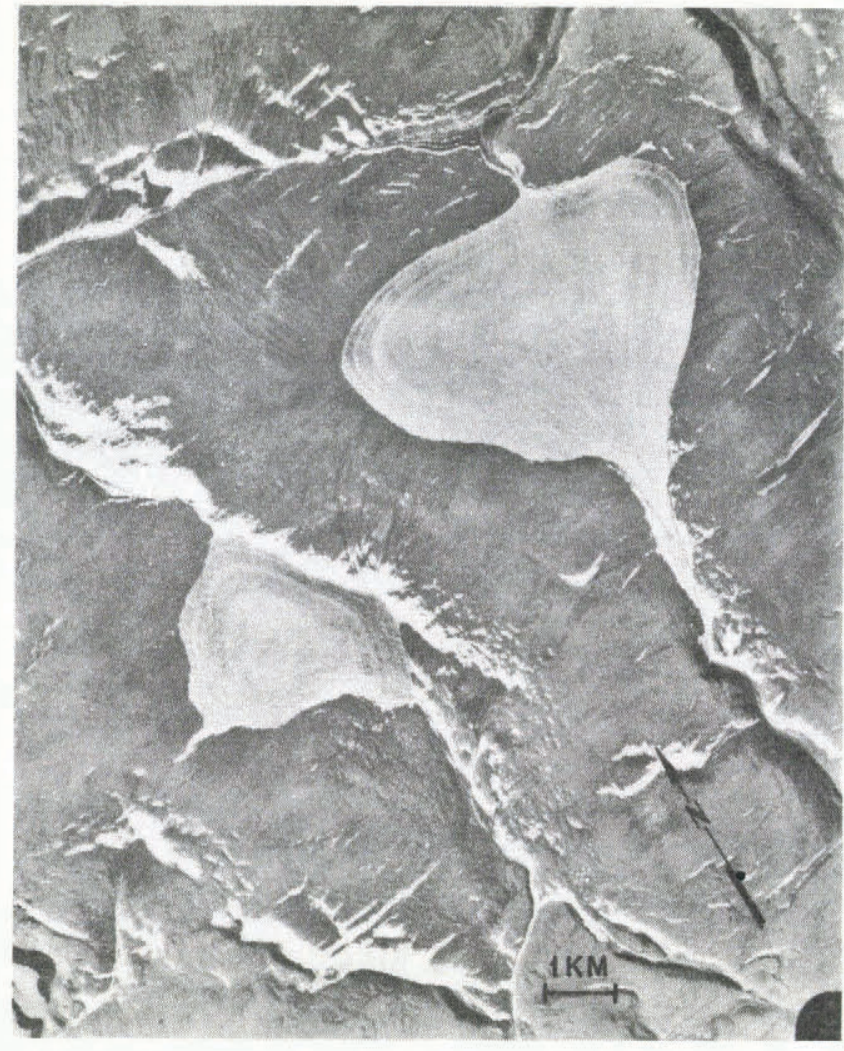

Fig. 3. Vertical aerial photograph of St. Patrick Bay ice caps. (Copyright: Canadian Government: air photograph A-16608-15, 6 July 1959.)

north-east-facing slope and ranges in elevation from $\sim 740$ to $\sim 820 \mathrm{~m}$ a.s.l. It seems likely that this ice body formerly occupied the summit to the north-west (at $\sim 865 \mathrm{~m}$ ) and possibly the south-west, but continued ablation has resulted in ice only being able to survive in the most topographically favored site.

Mass-balance data are shown in Table III. Although Hattersley-Smith and Serson (1973) were impressed by the extensive firn on the plateau in the summer of 1972, the climatic conditions which led to that situation have not prevailed. From 1972-82, the net mass balance was quite

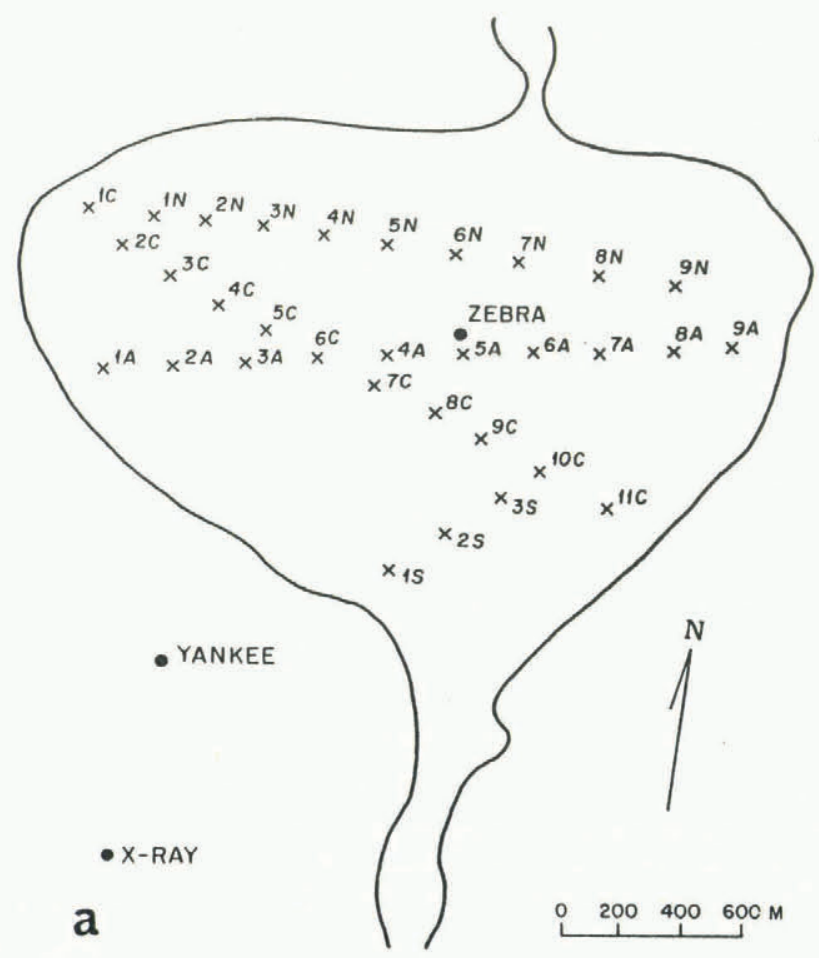

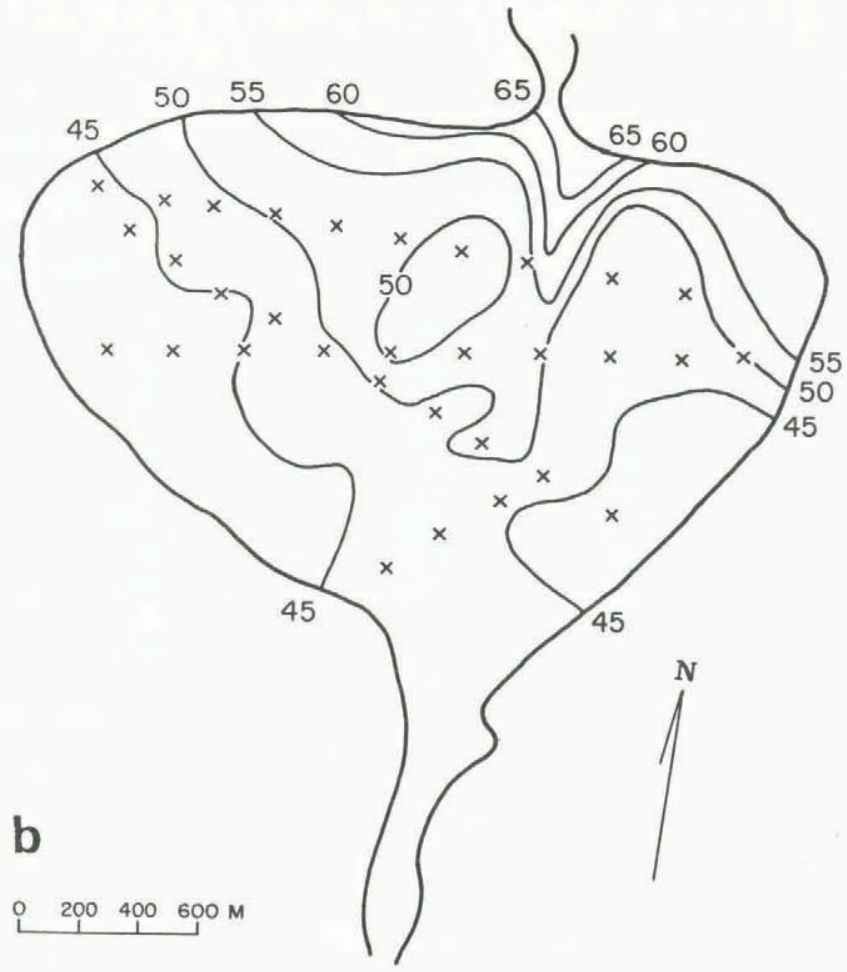

SNOW DEPTH SURVEY: June 8-14,1982

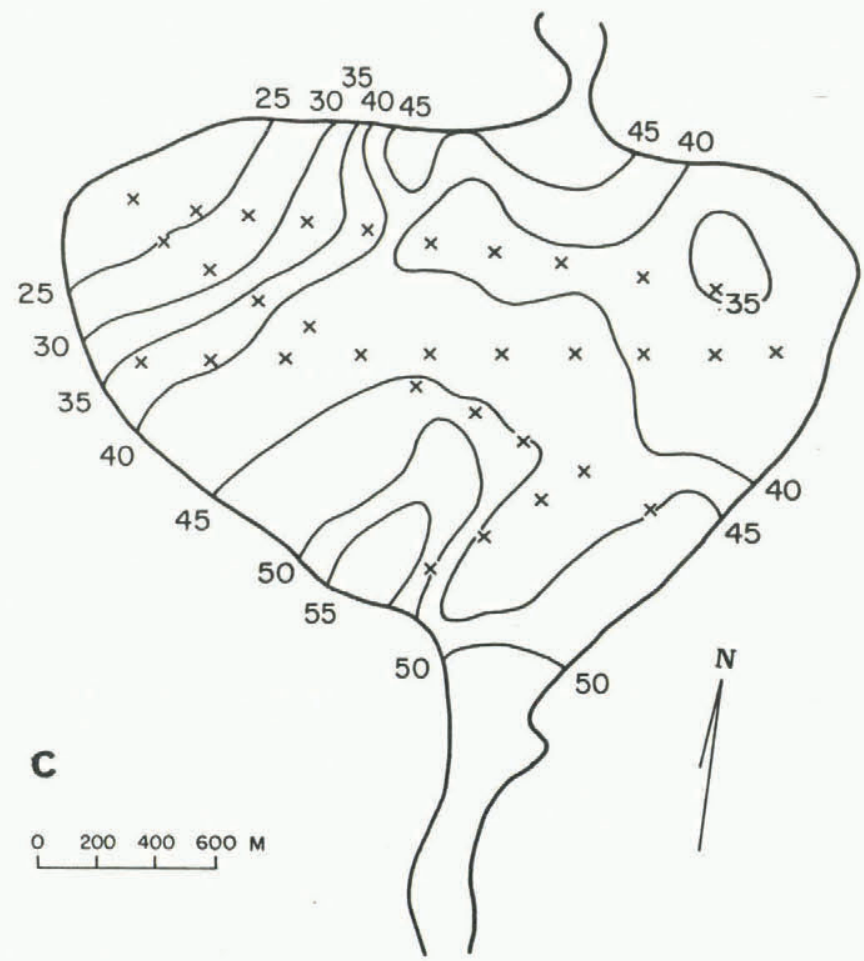

SNOW DEPTH SURVEY: June 16-20,1983

Fig. 4. (a) Ablation-stake network established on main ice cap. Zebra, Yankee, and $X$-ray refer to meteorological stations maintained in the summers of 1982 and 1983 (papers in preparation by R.S. Bradley and M.C. Serreze). (b) Snow-depth survey (cm), 8-14 June 1982. (c) Snow-depth survey $(\mathrm{cm}), 16-20$ June 1983. 
TABLE II. ELEVATION OF STAKES AND METEOROLOGICAL STATIONS (m) ON AND AROUND ST. PATRICK BAY ICE CAPS

\section{Meteorological stations}

$X$-ray 828

Yankee 842

Zebra 860

Stakes on large ice cap

$\begin{array}{ll}1 \mathrm{~N} & 887 \\ 2 \mathrm{~N} & 887 \\ 3 \mathrm{~N} & 881 \\ 4 \mathrm{~N} & 867 \\ 5 \mathrm{~N} & 855 \\ 6 \mathrm{~N} & 847 \\ 7 \mathrm{~N} & 848 \\ 8 \mathrm{~N} & 858 \\ 9 \mathrm{~N} & 865\end{array}$

*Stake missing in 1983.

$\begin{array}{llll}1 \mathrm{C} & 882 & 1 \mathrm{~A} & 892 \\ 2 \mathrm{C} & 894 & 2 \mathrm{~A} & 893 \\ 3 \mathrm{C} & 898 \text { (summit) } & 3 \mathrm{~A} & 885 \\ 4 \mathrm{C} & 894 & 4 \mathrm{~A} & 862 \\ 5 \mathrm{C} & 883 & 5 \mathrm{~A} & 858 \\ 6 \mathrm{C} & 871 & 6 \mathrm{~A} & 862 \\ 7 \mathrm{C}^{*} & 867 & 7 \mathrm{~A} & 867 \\ 8 \mathrm{C} & 863 & 8 \mathrm{~A} & 868 \\ 9 \mathrm{C} & 857 & 9 \mathrm{~A} & 854\end{array}$

Stakes on small ice cap

$\begin{array}{ll}1 & 810 \\ 2 & 790 \\ 3 & 773 \\ 4 & 759\end{array}$

negative $\left(-1300 \mathrm{~kg} \mathrm{~m}^{-2}\right.$ based on re-measurements of the 1972 stake line). This result is supported by changes in ice-cap area which are apparent between the 1959 and 1978 photographic surveys. We estimate that the larger and smaller St. Patrick Bay ice caps have decreased in area by $7 \%$ and $11 \%$, respectively, over this interval.

A network of 18 stakes was established on Simmonds Bay ice cap (Fig. 1) during 7-10 June 1976. This ice cap also occupies a small higher-elevation summit of the Hazen Plateau, but is considerably higher in elevation than the St. Patrick Bay ice caps and has greater relief, ranging from $<1050 \mathrm{~m}$ to $>1150 \mathrm{~m}$ (Bradley and England, 1977). The stake network was re-surveyed on 11 July 1983. Twelve of the original 18 stakes could not be located and are assumed to have melted out. Mass balance for the interval 1976-83 was estimated as follows. For the six remaining stakes, the difference between measurements in 1983 and 1976 of the distance from the ice surface to the top of each stake was calculated and multiplied by an assumed ice density of $0.9 \mathrm{Mg} \mathrm{m}^{-3}$. To this value, the difference in water equivalent of the snow and firn above the ice surface for the 2 years was subtracted (using calculated water equivalents in 1976 and estimated values in 1983). For the missing stakes, the amount of ice ablation was assumed to be only equivalent to the original depth of stake insertion into the ice. Weighting the resultant values at each stake to sub-areas of the ice cap (using Theissen polygons) gave a mean value of $-488 \mathrm{~kg} \mathrm{~m}^{-2}$. Clearly, this is a minimum estimate since the stakes which survived were all at higher elevation $(>1090 \mathrm{~m})$. It also appeared that marginal recession of the ice cap had occurred since the 1959 aerial photographic survey. Interestingly, stake B, at the summit of the ice cap,

TABLE III. MASS-BALANCE DATA FOR NORTHERN ELLESMERE ISLAND PLATEAU ICE CAPS*

St. Patrick Bay ice cap

$\mathrm{kg} \mathrm{m}^{-2}$
South-western

$\begin{array}{cc} & -1300 \\ & +159 \\ & -303 \\ & -144 \\ +183 & +118 \\ -18 & -19 \\ +165 & +137 \\ \text { ice cap } & \\ & -488 \\ & \text { Minimum estimate }\end{array}$

1976-83

Net balance

Simmonds Bay ice cap

Winter (12 Jun. 1982)

Summer (28 Jul. 1982)

Net

Winter (18 Jun. 1983)

Summer (27 Jul. 1983)

Net

* Rates in parentheses are times of initial and final snow surveys at the start and end of the field seasons.

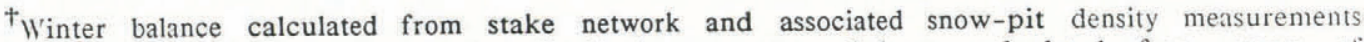
areally weighted by snow-depth distribution; summer balance calculated from mean of measurements at stakes. Net balance $1972-82$ and 1976-83 are averages of measurements at stake line. 
showed very little mass loss over the 1976-83 interval $\left(-10 \mathrm{~kg} \mathrm{~m}^{-2}\right)$, suggesting that the equilibrium line in the area has averaged around $1150 \mathrm{~m}$ during this period.

Detailed snow-depth and density measurements on the larger St. Patrick Bay ice cap in early June 1982 indicated a winter balance of $159 \mathrm{~kg} \mathrm{~m}^{-2}$. In 1983 , the figure was $118 \mathrm{~kg} \mathrm{~m}^{-2}$. This compares with an estimate of $140 \mathrm{~kg} \mathrm{~m}^{-2}$ for 1971-72 (Hattersley-Smith and Serson, 1973) though no snow-density measurements were made at that time and the survey was limited to the stake line. Ablation-season conditions in 1982 and 1983 were markedly different, resulting in quite different mass-balance conditions for each year. In 1982, mass losses of the previous decade (or more) continued at the same rate, resulting in a net balance for $1981-82$ of $-144 \mathrm{~kg} \mathrm{~m}^{-2}$. However, the summer of 1983 was much colder and snow was common throughout the normal ablation season. As a result, when the field party left at the end of July, there had been a net gain in mass on the ice cap of $137 \mathrm{~kg} \mathrm{~m}^{-2}$ for the 1982-83 year. Similarly, the smaller, south-western ice cap registered a net gain of $165 \mathrm{~kg} \mathrm{~m}^{-2}$. It is unlikely that subsequent conditions in August changed the situation significantly.

\section{DISCUSSION}

Although no long-term climatic data are available for the ice caps themselves, meteorological observations have been made at Alert, $\sim 70 \mathrm{~km}$ to the north, since 1950. These provide the best available index of long-term climatic variations in the region. Melting degree days (cumulative totals of daily above-freezing mean temperatures) are a useful index of total ablation-season warmth. Figure 5 shows annual and July totals of melting degree days (MDD) for the last 34 years. Three aspects of the record are worth noting: first, there is large inter-annual variability, particularly in the early part of the record. Secondly, there has been a statistically significant decline in MDD over the period of record, amounting to 22 MDD per decade, on average. Thirdly, it is clear that July MDD account for most of the summer "warmth", particularly in cold summers. The Alert record also enables the recent summers to be placed in a longer-time perspective. 1983 ranked in the lowest quartile of annual MDD, and the lowest decile of July MDD. This was obviously reflected in the positive mass-balance estimate for 1982-83. By contrast, 1982 had MDD totals closer to the average of the last 30 years. Judging by the MDD values for the period prior to the mid-1960s, and the fact that the ice caps have lost considerable mass during the $1970 \mathrm{~s}$, there seems little doubt that mass losses were considerably greater in the 1950 s and early 1960 s.

To investigate whether scattered glaciological

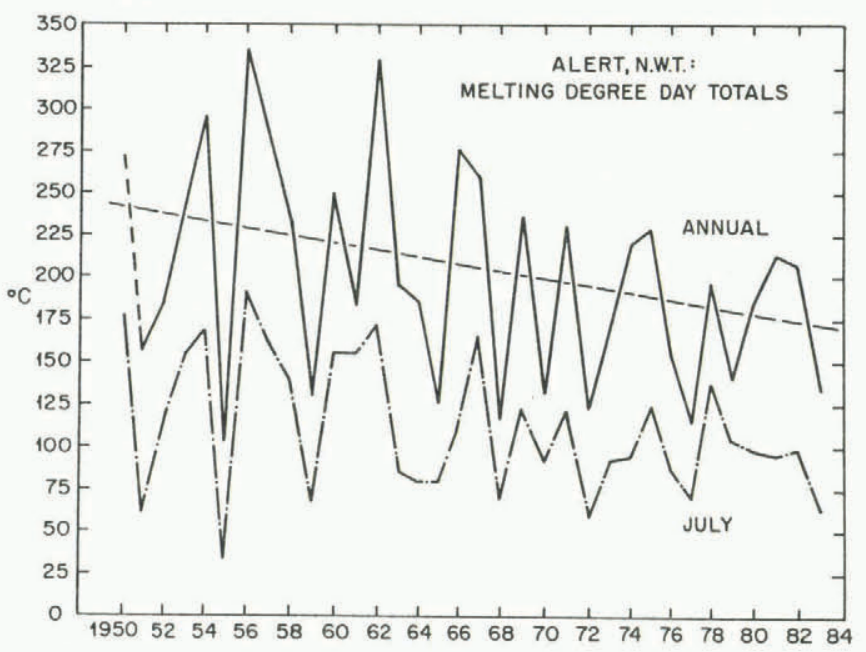

Fig. 5. Melting degree day totals $\left({ }^{\circ} \mathrm{C}\right)$ at Alert, annually (solid line) and for July (dashed line). Values derived from mean daily temperature. A linear regression on the anmual data $(y=-2.16 x+4454)$ is also shown. The correlation coefficient $(r)$ is $-0.34(p=0.02)$. observations on northern Ellesmere Island and/or photographic evidence could be used in conjunction with Alert data to provide a general yearly index of ice-cap mass balance, Alert winter precipitation totals were plotted against the subsequent summer MDD totals (Fig. 6). Four points on the diagram are well established; there was a

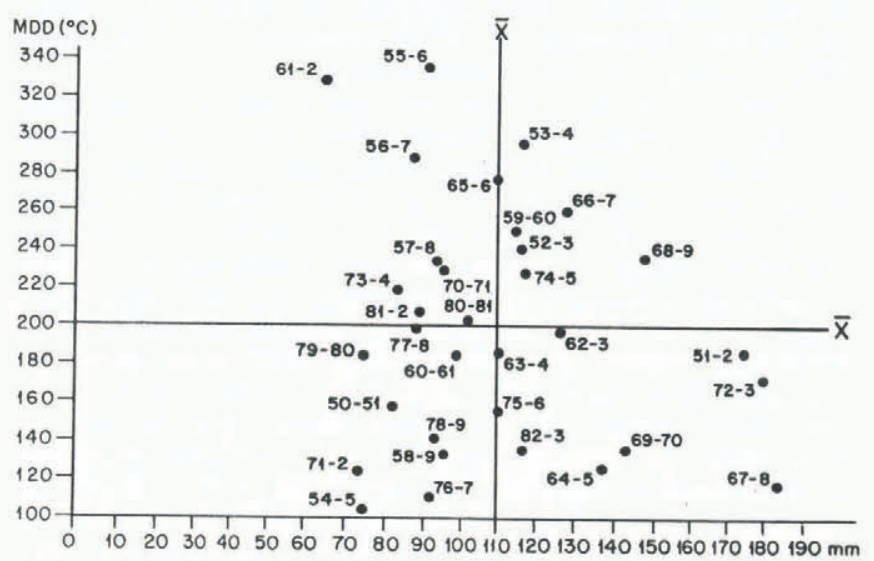

Fig. 6. Snowfall ( $\mathrm{mm}$ water equivalent) during winter months and melting degree days the following summer at Alert. Winter is defined as the time between the last period of mean daily temperatures continuously above $0^{\circ} \mathrm{C}$ for 5 days or more in the autumn and the first period of same in the spring (mean dates, 1951-83 were 25 August and 18 June).

very high negative mass balance in 1981-82 and also in 1977-78 when aerial photographs (taken in August 1978) showed a prominent ablation surface on the St. Patrick Bay ice caps. By contrast, $1971-72$ and 1982-83 were clearly very positive mass-balance years, according to field measurements. It is quite likely that $1963-64$ was a positive-balance year too; according to observations by Hattersley-Smith (1969) the snow line in mid-August 1964 near Tanquary Fiord ( $200 \mathrm{~km}$ to the south-west) was $\sim 850 \mathrm{~m}$. Other observations (e.g. Hattersley-Smith and Serson, 1970; Hattersley-Smith, 1972) indicate that this was probably representative of a larger area of northern Ellesmere Island. Mass-balance studies on Gilman Glacier in the 1950 s provide another assessment of ELAs in the region. In 1957 and 1958, ELAs in the area $(100 \mathrm{~km}$ west-south-west of the St. Patrick Bay ice caps) were $\sim 1240 \mathrm{~m}$ and $\sim 1200 \mathrm{~m}$, respectively (Hattersley-Smith and others, 1961), suggesting that 1956-57 and 1957-58 were negative mass-balance years on the St. Patrick Bay ice caps.

Comparison of all these observations with the Alert data suggests that positive-balance years are associated with summer MDD totals of $<190$. Winter snowfall variations seem to be of little significance. For example, the 1982-83 winter balance on the St. Patrick Bay ice caps was only $75 \%$ of the 1981-82 winter balance (cf. Alert; Fig. 6), yet the lower MDD of 1983 resulted in a positive mass balance. It should be noted, however, that the Alert data can only be used as a general guide to regional climate as conditions along the northern coastal strip of Ellesmere Island may be quite different from the interior. For example, data from Alert suggest that $1958-59$ should have been a very positive mass-balance year, but aerial photographs taken on 6 July (Fig. 3) clearly show the St. Patrick Bay ice caps devoid of snow with bare ice exposed. It is difficult to imagine how this situation arose, since (at least at Alert) mean daily temperatures had only been above $0^{\circ} \mathrm{C}$ for 2 weeks prior to this photographic survey. Possibly, the plateau had received very little snowfall during the winter and/or had been swept clear by strong winds. Alternatively, the Alert data may not have been representative of a wider area in 1959; indeed, Hattersley-Smith and Serson (1970), in their study of mass balance on the Ward Hunt Ice Shelf, noted that the ice shelf lost mass in 1959 and gained mass in 1964, when the Alert data suggest that the reverse would have been 
true. Year-to-year variations in wind strength may be an important factor in mass balance by influencing the redistribution of winter snowfall (cf. Fisher and others, 1983). Bearing in mind such problems, it nevertheless seems likely from the Alert data that the dominant tendency over the last 35 years has been towards mass losses, particularly during the 1950s. Interestingly, daily maximum temperatures at Alert during the $1950 \mathrm{~s}$ commonly exceeded $15.5^{\circ} \mathrm{C}$ (with an absolute maximum of $20^{\circ} \mathrm{C}$ recorded in 1956). Since 1963 , maxima have rarely even reached $15^{\circ} \mathrm{C}$.

Are the St. Patrick Bay ice caps a "sensitive" indicator of climatic variation, as Hattersley-Smith and Serson (1973) suggested? They are certainly vulnerable to small shifts in mean summer conditions but, given the range of MDD at Alert experienced over the last three decades, the ice caps are by no means in equilibrium with contemporary climate. In spite of occasional small mass-balance gains, larger mass losses in other years preclude any overall ice-cap growth. They are remnants of a period when MDD totals exceeding 200 must have been quite rare and/or when snowfall was very much higher than in recent years. Overall, the ice caps today are wasting away and will eventually disappear if contemporary conditions are any guide to the climate of the next century or two. In the sense that they provide no long-term record of climate, they do not really provide any better indication of climatic variability than the Alert instrumental record. A more useful "sensitive" indicator of regional climate, in the sense of providing a yard-stick by which to assess contemporary climatic variations, would be provided by a long continuous record from higher elevations such as the short ice core recovered from Gilman Glacier (Hattersley-Smith, 1963) or the long ice core recently recovered from Mer de Glace Agassiz $200 \mathrm{~km}$ to the south-west (Fisher and others, 1983) Monitoring of annual accumulation- and ablation-season conditions can then be placed in a longer-term perspective, beyond the limited 35 year instrumental record available for the High Arctic.

\section{CONCLUSIONS}

Mass-balance studies on small plateau ice caps of northern Ellesmere Island indicate significant wastage has occurred during the $1970 \mathrm{~s}$, in spite of occasional positivebalance years. Mass balance on the St. Patrick Bay ice caps was $-144 \mathrm{~kg} \mathrm{~m}^{-2}$ in $1981-82$ and $+137 \mathrm{~kg} \mathrm{~m}^{-2}$ in $1982-83$. Analysis of these and other regional glaciological and photographic observations has been attempted, to place the observations in a longer-term perspective. From this analysis, it is clear that over the last 30 years the ice caps must have lost considerable mass and that they are not in equilibrium with the climate of recent decades. They are remnants of a period in the past when MDD totals at Alert were rarely $>200$ and/or when snowfall was heavier. If contemporary conditions persist, the ice caps will disappear within the next $100-200$ years.

\section{ACKNOWLEDGEMENTS}

This work was supported by the U.S. National Science Foundation, grant ATM80-17745 to the University of Massachusetts. Logistical support was provided by the Polar Continental Shelf Project, Department of Energy, Mines and Resources, Ottawa. We are grateful to M. Palecki, C. Allen, M. Retelle, J. Fabel, and R. Friend for assistance in the field.

\section{REFERENCES}

Bradley, R.S., and England, J. 1977. The Simmonds Ice Cap. (In Bradley, R.S., and England, J., eds. Past glacial activity in the High Arctic. Amherst, MA, University of Massachusetts. Department of Geology and Geography, p. 177-82. (Contribution No. 31.))

Fisher, D.A., and others. 1983. Effect of wind scouring on climatic records from ice-core oxygen-isotope profiles, by D.A. Fisher, R.M. Koerner, W.S.B. Paterson, W. Dansgaard, N. Gundestrup, and N. Reeh. Nature, Vol. 301, No. 5897, p. 205-09.

Hattersley-Smith, G. 1963. Climatic inferences from firn studies in northern Ellesmere Island. Geografiska Annaler, Vol. 45, Nos. 2-3, p. 139-51.

Hattersley-Smith, G. 1969. Glacial features of Tanquary Fiord and adjoining areas of northern Ellesmere Island, N.W.T. Journal of Glaciology, Vol. 8, No. 52, p. 23-50.

Hattersley-Smith, G. 1972. Climatic change and related problems in northern Ellesmere Island, N.W.T., Canada. Acta Universitatis Ouluensis. Ser. A. Scientia Rerum Naturalium, No. 3. Geologica, No. 1, p. 137-48.

Hattersley-Smith, G., and Serson, H. 1970. Mass balance of the Ward Hunt ice rise and Ice Shelf: a 10 year record. Journal of Glaciology, Vol. 9, No. 56, p. 247-52.

Hattersley-Smith, G., and Serson, H. 1973. Reconnaissance of a small ice cap near St Patrick Bay, Robeson Channel, northern Ellesmere Island, Canada. Journal of Glaciology, Vol. 12, No. 66, p. 417-21.

Hattersley-Smith, G., and others. 1961. The ablation season on Gilman Glacier, northern Ellesmere Island, by $\mathrm{G}$. Hattersley-Smith, J.R. Lotz, and R.B. Sagar. Union Géodésique et Géophysique Internationale. Association Internationale d'Hydrologie Scientifique. Commission des Neiges et Glaces. Assemblée Générale de Helsinki 25-7-6-8 1960, p. 152-68. (Publication No. 54 de l'Association Internationale d'Hydrologie Scientifique.)

Miller, G.H., and others. 1975. The glaciation level and lowest equilibrium line altitude in the high Canadian Arctic: maps and climatic interpretation, by G.H. Miller, R.S. Bradley, and J.T. Andrews. Arctic and Alpine Research, Vol. 7, No. 2, p. 155-68. 